\title{
Pandemi Döneminde Üniversite Öğrencilerinin Akademik Motivasyon Düzeylerinin İncelenmesi
}

\author{
Makbule Hürmet ÇETINEL*, Sinan GÜRCÜOĞLU**
}

ÖZ

Motivasyon, bireyin güdülenerek bir davranışı sergilemesini açıklamaktadır. Akademik motivasyon ise, bireyi öğrenim hayatı için bir davranışa ve çalışmaya yönlendiren güç olarak ifade edilebilir. Motivasyon bireyi başarıya ulaşmaya veya bir amacı gerçekleştirmeye bilinçli olarak yöneltir. Bu çalışmada, üniversite öğrencilerinin akademik motivasyon düzeyleri incelenmiştir. Çalışmanın amacı, tüm dünyayı etkisi altına alan pandemi döneminde üniversite öğrencilerinin akademik motivasyon düzeylerinin demografik faktörler açısından belirlenmesidir. Elde edilen sonuçlara göre, pandemi döneminde üniversite öğrencilerinin akademik motivasyon düzeyleri ile demografik faktörler arasında ilişki olduğu bulunmuştur. Covid-19 hastalığı geçiren üniversite öğrencilerinin başarıya yönelik içsel motivasyon düzeylerinin düşük olduğu, ailesinde Covid-19 hastalığ 1 geçirenlerde ise, bilmeye yönelik içsel motivasyonlarının düşük olduğu tespit edilmiştir.

Anahtar Kelimeler: Motivasyon, Akademik Motivasyon, Covid-19

JEL Sinıflandırması: M1, M10, M19

\section{Investigation of University Students' Academic Motivation Levels in the Period of Pandemic}

\begin{abstract}
Motivation explains how an individual exhibits a behavior by being motivated. Academic motivation, on the other hand, can be expressed as the power that directs the individual to a behavior and work for his learning life. In this study, academic motivation levels of university students were examined. The aim of the study is to determine the academic motivation levels of university students in terms of demographic factors during the pandemic period that affected the whole world. According to the results, it was found that there is a relationship between the academic motivation levels of university students and demographic factors during the pandemic period. It has determined that university students with Covid-19 disease have low levels of intrinsic motivation for success, while those with a family history of Covid-19 have low intrinsic motivation to know.
\end{abstract}

Keywords: Motivation, Academic Motivation, Covid-19

JEL Classification: M1, M10, M19

Geliş Tarihi / Received: 30.06.2021 Kabul Tarihi / Accepted: 26.08.2021 Doi: 10.17541/optimum.960301

\footnotetext{
* Dr. Öğr. Üyesi, Uşak Üniversitesi, Uygulamalı Bilimler Fakültesi, Lojistik Bölümü, hurmet.cetinel@usak.edu.tr, ORCID: 0000-0003-3260-7432

** Dr. Öğr. Üyesi, Uşak Üniversitesi, Adalet Meslek Yüksekokulu, Hukuk Bölümü, sinan.gurcuoğlu@usak.edu.tr, ORCID: 0000-0003-1000-4761
} 


\section{GİRİŞ}

Çin'de 2019 yılı sonunda ortaya çıkan Covid-19 hastalığı kısa süre içinde dünya genelinde etkili olmuş ve bu süreç pandemi olarak adlandırılmıştır. Covid-19 hastalığı yayılma hızının yüksek oluşu nedeniyle kısa süre içinde ve hızlı bir şekilde küresel düzeyde sosyal hayatı etkisi altına almıştır. Salgının etkilerini azaltmak ve yayılımını durdurmak için en etkili önlemlerden biri olan sosyal mesafe kuralı, özellikle eğitim sektörünü olumsuz etkilemiş ve yüz yüze eğitimlerin yapılmasını engellemiştir. Ülkemizdeki tüm üniversiteler Covid-19 pandemi döneminde uzaktan eğitim yöntemi ile eğitimlerini sürdürme kararı almışlardır. $\mathrm{Bu}$ süreçte öğrencilerin motivasyonlarını etkileyen unsurlar değişmiş, olağan dönemlerde çok da etkili olamayan bazı unsurlar pandemi döneminde çok daha etkili hale gelmiştir.

Pandemi sürecinin bireyler üzerinde fiziksel ve ruhsal etkilerinin olabileceği düşüncesinden hareketle bu çalışmada, üniversite öğrencilerinin pandemi döneminde akademik motivasyon düzeyleri araştırılmıştır. Bireyin davranış şekillerini etkileyen ve bireyi güdüleyen bir süreç olarak motivasyon, bireyin harekete geçmesini sağlayan istek ve amaç olarak ifade edilebilmektedir. Bireyin hem iş yaşamında hem de iş dışı yaşamında önemli bir yeri olan motivasyon kavramı, bireyin amaçları doğrultusunda harcaması gereken çabayı artıran bir etkiye sahiptir. Akademik motivasyon, bireyin eğitim hayatı ile ilgili amaç ve hedeflerini gerçekleştirmede bireyi yönlendirmektedir. Bu çalışmanın amacı, pandemi döneminde üniversite öğrencilerinin motivasyon düzeylerini tespit etmektir. Bu amaca yönelik olarak 2020/2021 eğitim- öğretim yılı bahar döneminde Uşak Üniversitesi’nde öğrenim gören öğrenciler üzerinde bir araştırma gerçekleştirilmiştir. Araştırmanın verileri, sekiz farklı bölümden 351 fakülte ve yüksekokul öğrencisinin katılımı ile elde edilmiştir. Çalışmanın sonucunda pandemi nedeniyle öğrencilerin kariyer planlarında değişiklikler olduğu, kendisi Covid-19 hastalığ 1 geçiren ve ailesinde Covid-19 hastalığ geçiren kişi bulunan öğrencilerle, Covid-19 hastalığ 1 geçirmeyen öğrencilerin motivasyon düzeyleri arasında farklılıklar olduğu bulgulanmıştır. Alanyazında olağan dönemlerde öğrencilerin motivasyon düzeylerini belirlemeye yönelik farklı çalışmalar bulunmakla birlikte pandemi döneminde yapılmış bir çalışmaya rastlanılmamıştır. $\mathrm{Bu}$ ise, çalışmanın özgün yönünü oluşturmaktadır. İlgili kurum ve kuruluşlar tarafından pandemi döneminde öğrencilerin motivasyon düzeylerini artırmaya yönelik alınacak tedbirlerin belirlenmesinde çalışmanın yol gösterici olabileceği ve bu sayede alanyazına özgün katkılar sağlanacağı düşünülmektedir. Ayrıca konunun pandemi döneminde incelenmesi ve karşılaştırma yapmaya imkân sağlayacak olması nedeniyle de başka çalışmalara 1şık tutabileceği söylenebilir.

\section{KAVRAMSAL ÇERÇEVE}

\subsection{Motivasyon}

Motivasyon, bireyleri davranışlara yönelten ve bu davranışlara yön verip, davranışların devamlılığını sağlayan içsel ve dışsal kaynakların işleyiş mekanizmalarını içermektedir (Akbaba, 2006: 347). Motivasyon, bireyin önceliklerini belirlemesi ve belirli güdülerin etkisi ile harekete geçmesi ve beklenen davranışı oluşturma süreci olarak da tanımlanmaktadır. Bu süreçte bireyi harekete geçirecek olan temel kavramlar ise amaç, davranış ve ihtiyaçlardır (Şenturan, 2014: 22). Başaran (2008: 90)'a göre motivasyon; bireyi bir amacı gerçekleştirmeye bilinçli olarak yönelten güdü ve içten gelen güç olarak tanımlanmaktadır. Bu güç, bireyi kendiliğinden bir davranışı yapmaya yönlendirmede, bireyi eyleme geçirmede ve beklenen davranış1 gerçekleştirmesi sürecinde belirleyici olmaktadır. Bu süreçte birey etkinlik için harekete geçmekte ve istediği başarıyı elde edene kadar etkin kalarak amacına ulaşmaktadır. Bireyler, iş ve iş dışı yaşam alanlarında motivasyona ihtiyaç duymaktadırlar. Her yaşam alanının özellikleri birbirinden farklı olsa da bireyler için motivasyon olması gereken bir kavramdır. Amaçların gerçekleştirilmesi, çabalar ve beklentiler konusunda bireyin hayatında motivasyonun önemli bir yeri bulunmaktadır 
(Zencirkıran ve Keser, 2018: 200). Bireyin hedeflere ilişkin davranışları ve bu hedeflere ulaşmak için gösterdiği çabalar motivasyonu oluşturur. Motivasyon, bireyin davranışlarının nedenini açılayan uygulamalı bir yapı olarak da ifade edilebilmektedir (Brophy, 2012: 3-4).

Öz Belirleme Kuramı kapsamında motivasyon içsel ve dışsal motivasyon ve motivasyonsuzluk olarak gruplandırılabilir. Bu kuram özerk ve kontrollü motivasyonların altında yer alan unsurun hem düzenleyici süreçler hem de bu sürece eşlik eden deneyimler açısından farklı1ık gösterdiğini varsayar. Davranışların otonom ve kontrollü olma derecesi açısından karakterize edilebileceğini ileri sürmektedir (Ryan ve Deci, 2000: 72). İçsel olarak motive edilmiş bir davranışta birey, faaliyetin kendisine olan ilgisinden kaynaklanan otonom kontrolü sağlayarak, kendi kendini motive edebilmektedir. Dışsal motivasyon ise, otonom ve kontrollü olma derecesine göre değişebilir. Dışsal motivasyon, içsel olarak motive edici olmayan durumlarda ortaya çıkmaktadır. Bu nedenle davranışın ilk olarak gerçekleştirilmesi davranış ile ilgili örtülü onay veya somut ödüller gibi istenen bir sonuç arasındaki olasıllk algısına bağlıdır. D1ş düzenleme, dışsal motivasyonun içsel motivasyonla karşılaştırıldığı zaman göz önünde bulundurulan dişsal motivasyon türüdür. Diğer dişsal motivasyon türleri bir davranışsal düzenleme ve onunla ilişkili değer içselleştirildiğinde ortaya çıkar. İçselleştirme, bir davranışın dış düzenlemesinin bir iç düzenlemeye dönüştüğü ve dolayısıyla artık bir dış koşul gerektirmeyen değerleri, tutumları veya düzenleyici yapıların benimsenmesidir. İçe yönelik düzenleme kişinin içindedir, ancak nispeten kontrollü bir içselleştirilmiş dişsal motivasyon biçimidir (Gayne ve Deci, 2005: 334). Vallerand vd. (1992: 1005-1008) içsel motivasyonu; bilmeye yönelik içsel motivasyon, başarıya yönelik içsel motivasyon, uyarım yaşamaya yönelik içsel motivasyon olarak gruplandırmaktadır. Dışsal motivasyonu; belirlenmiş düzenleme, içe yansıyan dış motivasyon ve dişa bağlı düzenleme olarak belirtmiştir. Deci ve Ryan (2000: 240242), motivasyonsuzluk alt boyutunu ise, kişisel olmayan nedensellik yönelimi temel ihtiyaç eksikliğinden kaynaklandığını belirtmiştir. Motivasyonsuzluk bireyin harekette bulunma isteğinden yoksun olma durumunu ifade etmektedir.

\subsection{Akademik Motivasyon}

Akademik motivasyon, akademik amaçlara ulaşmak için öğrencilerin belirli olan amaç doğrultusunda gösterdikleri çaba ve isteklilik halini ifade etmektedir. Öğrenmeye ilişkin motivasyon kavramı ile benzer anlamları açıklamaktadır (Gömleksiz ve Serhatlıoğlu, 2013: 103). Akademik motivasyon, yeni bir şeyler öğrenmek için yoğun şekilde çalışmak ve bununla ilgili tutum ve davranışlar geliştirip, öğrencinin bir çalışmayı, ödevi, projeyi vb. görevleri başarılı bir şekilde sürdürebilmesini ve mevcut performansını değerlendirebilmeyi sağlar. Yeni şeyler öğrenme konusunda bireyi güdüleyen, çaba gerektiren görevleri devam ettirebilmeyi içermektedir (Günaydın, 2021: 2). Korkmazer (2020), akademik motivasyonu yüksek olan öğrencilerin derslere karşı olumlu tutum içinde olduklarını başarı ve performanslarının yüksek olduğunu belirtmiştir. Elde ettiği bulgulara göre, akademik motivasyon eğitim düzeyi, bölüm ve not ortalamasına göre farklılık göstermektedir. Özkan vd. (2015), öğrencilerin liderlik davranış1 ile motivasyon düzeyleri arasında ilişki olduğunu ileri sürmüştür. Akademik başarısı yüksek olan öğrencilerin karizmatik liderlik tarzı sergileme düzeylerinin yüksek olduğunu belirtmiştir. Terlemez vd. (2015), sağlık hizmetleri meslek yüksekokulu öğrencilerinin akademik motivasyon düzeylerini incelemiştir. Öğrencilerinin motivasyon seviyeleri içe yansıyan dışsal motivasyon, dışsal motivasyon-dış düzenleme boyutlarında daha yüksek düzeyde olduğunu bulgulamıştır. Yılmaz vd. (2016), akademik motivasyon ile cinsiyet, sınıf değişkenleri arasında farklılık olduğunu tespit etmiştir. Kız öğrencilerin motivasyonları erkek öğrencilere göre anlamlı olarak yüksek düzeydedir.

Akademik motivasyon ve akademik başarı arasında ise anlamlı bir ilişkinin olmadığı bulgusu belirtilmiştir. Romero vd. (2018), sosyoekonomik olarak dezavantajlı topluluklarda 
şiddetin eğitim ve akademik motivasyon üzerindeki etkilerini incelemiştir. Bulgulara göre, daha sik çok şiddete maruz kalan ergenler ve daha az sıklıkla çoklu şiddete maruz kalan ergenler olarak gruplara ayrılmıştır. Daha sık çoklu şiddete maruz kalmak daha düşük akademik motivasyonu ortaya çıkarmıştır. Bu durumdaki ergenler yüksek oranda başarıyı istemektedirler. Bulgular, daha sık çoklu şiddete maruz kalmanın arttığını göstermektedir. Dezavantajlı topluluklardan gelen ergenler arasında okul gecikmesi riski akademik motivasyonu etkilememektedir. Yüksek şiddet sıklığı okulda başarılı olma isteğini, hedefleri sürdürme ve yüksek şiddet sıklığı bu amaçları gerçekleştirme kapasitesini etkilemiştir. Rowel ve Hong (2013), içsel ve dışsal motivasyonların ögrencilerin öğrenme süreçlerini etkileyen motivasyonel bileşenler olduğunu ifade etmektedir. Lia vd. (2020), akran ilişkileri ile matematik dersi başarısı arasındaki ilişkide öz-yeterlilik ve akademik motivasyonun aracılık rollerini araştırmıştır. Kadınların akran ilişkileri ve akademik motivasyon düzeyleri erkeklerden yüksektir. Akran ilişkileri matematik başarısı üzerinde anlamlı derecede olumlu bir etkiye sahiptir. Akran ilişkisi ve matematik başarısı arasındaki ilişkide akademik motivasyonun aracı rolü olduğunu bulgulamıştır. Kadınların akran ilişkileri ile motivasyonları arasındaki ilişkide özyeterlilik 1lımlı bir rol oynamıştır. Sanaie vd. (2019), öz-düzenlemeli öğrenme ve akademik motivasyon ilişkisini ileri sürmüştür. Öz düzenlemeli öğrenme bireyin kendi kendine öğrenebilmesi, kendi amaçlarını belirleyebilmesidir. Moghadam vd. (2020), motivasyonun akademik tükenmişlik üzerinde etkili olduğunu bulgulamıştır. Clark ve Schroth (2010), kişilik ve akademik motivasyon arasında ilişki olduğunu ileri sürmüştür. Elde edilen bulgulara göre; İçsel motivasyon, dışa dönük, uyumlu, sorumlu ve deneyimlere açıklık ile ilişkilidir. Dışsal motivasyon dışa dönük, uyumlu, sorumlu ve nevrotik olma eğilimi ile ilişkili olduğu sonucuna ulaşmıştır. Tam vd. (2020), öğrencilerin öğrenme motivasyonunda duygusal zekâ ve akademik başarının önemi olduğunu vurgulamıştır. Öğrencilerin öğrenme motivasyonlarının artması ile akademik başarılarını geliştirilebileceği bulgusuna ulaşmıştır. Xie vd. (2020), motivasyon, katılım ve akademik performans ilişkisini incelemiştir. Katılım için bilişsel ve sosyal katılım boyutu ele alınmıştır. Bilişsel katılım ve sosyal katılım motivasyonel bağl1lık ve akademik performans arasındaki ilişkiyi yönettiği sonucunu belirtmiştir. Nye vd. (2021), mesleki ilgilerin motivasyon, memnuniyet ve akademik performans ile ilgili olduğunu vurgulamıştır. Elde ettiği araştırma sonuçlarına göre, mesleki ilgi uyumunun performans, vatandaşlık davranışı üzerinde doğrudan etkileri olduğunu, üretkenlik karşıtı davranış ve bilişsel yeteneği kontrol ettikten sonra bile ayrılma niyeti ve dürüstlük üzerinde etkili olduğunu hem motivasyon hem de memnuniyet değişkenlerinin aracı etkisi olduğunu göstermiştir. Grigoryeva ve Shamionov (2014), akademik motivasyon ve öznel iyi oluşun akademik uyum için önemli faktörler olduğunu ileri sürmüştür. Yapılan bu çalışmalar ışığında akademik motivasyonun farklı değişkenler üzerinde etkisi olduğu belirtilebilir.

\section{YÖNTEM}

Çalışmanın temel amacı, pandemi döneminde üniversite öğrencilerinin akademik motivasyon düzeylerini belirlemektir. Araştırmanın evrenini Uşak Üniversitesi öğrencileri oluşturmaktadır. Evrenin tamamına ulaşmak mümkün olmadığ 1 için örneklem seçimine gidilmiştir. Örnekleme yöntemi olarak kolayda örnekleme yöntemi seçilmiştir. Pandemi döneminde alınan önlemler kapsamında yüz yüze anket yapılamadı̆̆ı kısıtı dolayısıyla anket formu, online olarak araştırmaya katılmak isteyen öğrencilere uygulanmıştır. Etik kurul izinleri 09/03/2021 tarihli 2021-49 sayılı karar ile alınan anketler online anket toplama yöntemi ile elde edilmiştir. Bu kapsamda 351 öğrenci ankete katılım göstermiştir. Veri toplama aracı olarak, Vallenrand vd. (1989) tarafindan geliştirilen ve içsel motivasyon, dişsal motivasyon ve motivasyonsuzluk olmak üzere üç alt boyutu bulunan akademik motivasyon ölçeği kullanılmıştır. Katılımcılara ölçekle birlikte demografik faktörlere ilişkin sorular da yöneltilmiştir. Özgün (2019) tarafından Türkçeye çevrilen 28 maddelik 7'li likert tipi ölçeğin 
Cronbach Alpha katsayısı 0,885 olarak yüksek derecede güvenilir bulunmuştur. Bu çalışmada ise, Cronbach Alpha katsayısı 0,919 olarak yüksek derecede güvenilir bulunmuştur.

\section{BULGULAR}

Tablo 1: Katılımc1ların Demografik Karakteristikleri

\begin{tabular}{|c|c|c|}
\hline$(n=351)$ & Sayı & Yüzde \\
\hline \multicolumn{3}{|l|}{ Eğitim Alanı } \\
\hline MYO & 131 & 37,3 \\
\hline Fakülte & 220 & 62,7 \\
\hline \multicolumn{3}{|l|}{ Yaş } \\
\hline 18-20 Yaş & 120 & 34,2 \\
\hline 21-23 yaş & 201 & 57,3 \\
\hline 24 Yaş ve Üzeri & 30 & 8,5 \\
\hline \multicolumn{3}{|l|}{ Cinsiyet } \\
\hline Kadın & 220 & 62,7 \\
\hline Erkek & 131 & 37,3 \\
\hline \multicolumn{3}{|l|}{ Bölüm } \\
\hline Adalet & 87 & 24,8 \\
\hline İşletme & 17 & 4,8 \\
\hline Lojistik & 104 & 29,6 \\
\hline Moleküler Biyoloji & 53 & 15,1 \\
\hline Muhasebe & 22 & 6,3 \\
\hline Sosyal Güvenlik & 23 & 6,6 \\
\hline Turizm Otelcilik & 7 & 2,0 \\
\hline Uluslararası Ticaret & 27 & 7,7 \\
\hline Diğer & 11 & 3,1 \\
\hline \multicolumn{3}{|l|}{ Sinıf } \\
\hline 1.Sinif & 86 & 24,5 \\
\hline 2. Sinif & 117 & 33,3 \\
\hline 3. Sinif & 48 & 13,7 \\
\hline 4. Sinif & 100 & 28,5 \\
\hline \multicolumn{3}{|l|}{ Gelir } \\
\hline 2500 aşağ1 & 153 & 43,6 \\
\hline $2501-4000$ & 47 & 13,4 \\
\hline $4501-6500$ & 115 & 32,8 \\
\hline 6501-yukar1 & 36 & 10,3 \\
\hline \multicolumn{3}{|c|}{ COVID-19 Geçirme Durumu } \\
\hline Evet & 58 & 16,5 \\
\hline Hayır & 293 & 83,5 \\
\hline \multicolumn{3}{|c|}{ Ailenizde COVID-19 Geçirme Durumu } \\
\hline Evet & 105 & 29,9 \\
\hline Hayır & 246 & 70,1 \\
\hline \multicolumn{3}{|c|}{ Mesleğe Bakış Açısı Değişimi } \\
\hline Evet & 266 & 75,8 \\
\hline Hayır & 85 & 24,2 \\
\hline \multicolumn{3}{|c|}{ Pandemi Dönemi Kariyer Planı Değişim } \\
\hline Evet & 265 & 75,5 \\
\hline Hayır & 86 & 24,5 \\
\hline
\end{tabular}

Tablo 1'e göre çalışmaya Uşak Üniversitesi'nin farklı bölümlerinde eğitim alan toplam 351 öğrenci katılım göstermiştir. Çalışmaya katılan kişilerin \%62,7’si kadın, \%37,3‘ü erkektir. 
Katılımcıların \%34,2‘si 18-20 aralı̆̆ında, \%57,3’ü 21-23 yaş aralığında ve \%8,5‘i 24 yaş ve üzeri yaş grubunda yer almaktadır. Katılımcıların \%16,5'i Covid-19 hastalığ 1 geçirmiş, \%83,5'i Covid-19 hastalığ geçirmemiştir. \%9,9'unun ailesinde Covid-19 hastalığ 1 geçiren kişi ya da kişiler bulunmakta, \%70,1'inin ailesinde ise, Covid-19 hastalığ 1 geçiren kişi ya da kişiler bulunmamaktadır. Katılımcıların pandemi döneminde \%75,8'inin mesleklere bakış açısı değişmiştir; \%24,2'sinin mesleklere bakış açısı ise bu dönemde değişmemiştir. \%75,5'inin kariyer planları pandemi döneminde değişmiş, \%24,5 'inin ise kariyer planı değişmemiştir.

Tablo 2: Ölçek ve Alt Boyutları İçin Tanımlayıcı İstatistikler ve Güvenilirlik Değerleri

\begin{tabular}{lcccc}
\hline Akademik Motivasyon Ölçeği / Alt Boyutları & $\mathbf{N}$ & Ort. & S.S. & Güvenilirlik \\
İçe yansıyan dışsal motivasyon & 345 & 4,4952 & 1,55218 & 0,774 \\
Başarıya yönelik içsel motivasyon & 344 & 4,5618 & 1,45019 & 0,786 \\
Uyarım yaşamaya yönelik içsel motivasyon & 347 & 4,6110 & 1,47312 & 0,814 \\
Motivasyonsuzluk & 346 & 5,4784 & 1,55047 & 0,796 \\
Bilmeye yönelik içsel motivasyon & 349 & 5,6012 & 1,26327 & 0,821 \\
Belirlenmiş dışsal motivasyon & 350 & 5,6879 & 1,22145 & 0,774 \\
Dişsal motivasyon - dış düzenleme & 350 & 5,7524 & 1,11238 & 0,479 \\
Akademik Motivasyon Ölçeği & 350 & 5,1788 &, 99073 & 0,919 \\
\hline
\end{tabular}

Tablo 2'de akademik motivasyonun ortalamaları bulunmaktadır. Bu sonuçlara göre; akademik motivasyon ölçeğinin genel ortalaması 5,17 ve standart sapma değeri 0,990 olarak görülmüştür. En yüksek ortalama 5,75 ile dışsal motivasyon alt boyutunda yer alan dış düzenleme boyutuna ait iken; en düşük ortalama ise 4,49 ile içe yansıyan dışsal motivasyon alt boyutunda gerçekleşmiştir.

Tablo 3: Cinsiyete Göre Ölçek ve Alt Boyutlarının Farklılıklarının İncelenmesi

\begin{tabular}{cccccc}
\hline & Cinsiyet & N & Ortalama & t-Testi & Anlamlılık \\
Motivasyonsuzluk & Kadın & 217 & 5,6263 & & \\
& Erkek & 129 & 5,2297 & 2,315 & 0,021 \\
\hline
\end{tabular}

Tablo 3'te kadın katılımcıların erkeklere göre, istatistiksel olarak anlamlı bir şekilde daha fazla motive olduklarını göstermektedir. Diğer alt boyutlarda ve ölçek ortalamasında kadın ve erkek katılımcılar açısından anlamlı bir farklılık bulunamamıştır.

Tablo 4: Covid-19 Olma Durumuna Göre Ölçek ve Alt Boyutlarının Farklılıklarının İncelenmesi

\begin{tabular}{lccccc}
\hline Faktörler & Covid Oldunuz mu? & N & Ortalama & t-Testi & Anlamlılık \\
Başarıya & Evet & 57 & 4,2091 & & 0,045 \\
$\begin{array}{l}\text { Yönelik İçsel } \\
\text { Motivasyon }\end{array}$ & Hayır & 287 & 4,6318 & 2,019 & \\
\hline
\end{tabular}


Tablo 4'te Covid-19'a yakalanan katılımcıların, yakalanmayanlara göre "Başarıya Yönelik İçsel Motivasyon"larının istatistiksel olarak anlamlı şekilde daha az gerçekleştiği anlaşılmıştır.

Tablo 5: Ailedeki Bireyin Covid-19 Olma Durumuna Göre Ölçek ve Alt Boyutlarının Farklılıklarının İncelenmesi

\begin{tabular}{lccccc}
\hline Faktörler & $\begin{array}{c}\text { Ailenizde Covid } \\
\text { Geçiren Var mı? }\end{array}$ & $\mathbf{N}$ & Ortalama & t-Testi & Anlamlılık \\
Bilmeye Yönelik & Evet & 105 & 5,3968 & $-1,991$ & 0,047 \\
İçsel Motivasyon & Hayır & 244 & 5,6892 & & \\
\hline
\end{tabular}

Tablo 5'te katılımcılardan ailesinde Covid-19 geçirmiş olanların, geçirmeyenlere göre "Bilmeye Yönelik İçsel Motivasyon"larının istatistiksel olarak anlamlı şekilde daha az gerçekleştiği bulgulanmıştır.

Tablo 6: Kariyer Planları İle İlgili Yeni Karar Alma Durumuna Göre Ölçek ve Alt Boyutlarının Farklıl1klarının İncelenmesi

\begin{tabular}{lccccc}
\hline Faktörler & $\begin{array}{c}\text { Pandemi Döneminde Kariyer } \\
\text { Planlarınızda Değişiklik Oldu mu? }\end{array}$ & N & Ortalama & $\begin{array}{c}\text { t- } \\
\text { Testi }\end{array}$ & Anlamlılık \\
Bilmeye Yönelik İçsel Motivasyon & Evet & 263 & 5,7256 & 2,987 & 0,03 \\
& Hayır & 86 & 5,2209 & & \\
Başarıya Yönelik İçsel & Evet & 258 & 4,7051 & & \\
Motivasyon & Hayır & 86 & 4,1318 & 3,218 & 0,01 \\
Uyarım Yaşamaya Yönelik İçsel & Evet & 261 & 4,7625 & & \\
Motivasyon & Hayır & 86 & 4,1512 & 3,388 & 0,01 \\
Akademik Motivasyon Ölçeği & Evet & 264 & 4,8237 & & \\
Ortalaması & Hayır & 86 & 4,5099 & 3,03 & 0,03 \\
\hline
\end{tabular}

Tablo 6'ya göre, pandemi döneminde kariyer planlamalarını değiştiren katılımcılar ile değiştirmeyen katılımcıların akademik motivasyonu ile içsel motivasyona ait bilmeye yönelik içsel motivasyon, başarıya yönelik içsel motivasyon ve uyarım yaşamaya yönelik içsel motivasyon alt boyutlarında istatistiksel olarak anlamlı bir farklılık olduğu tespit edilmiştir. Buna göre pandemi döneminde kariyer planlarını değiştirdiğini ifade eden katılımcıların, değiştirmediğini söyleyenlere göre anlamlı şekilde motivasyonlarının yüksek olduğu görülmüştür. Dış motivasyon boyutlarında ise, istatistiksel olarak anlamlı bir farklılık bulunamamıştır.

Tablo 7: Bölümlere Göre Ölçek ve Alt Boyutlarının Farklılıklarının İncelenmesi

\begin{tabular}{lccccc}
\hline Faktörler & Bölüm & $\mathbf{N}$ & Ortalama & F & Anlamlılık \\
İçe Yansıyan Dışsal & İşletme & 17 & 3,4020 & & \\
Motivasyon & Moleküler Biyoloji & 53 & 4,7453 & 2,143 & 0,032 \\
\multirow{2}{*}{ Motivasyonsuzluk } & Adalet & 84 & 5,9310 & & \\
& Turizm Otelcilik & 7 & 3,8857 & & \\
& Uluslararası Tic. & 27 & 4,7926 & & 0,007 \\
\hline
\end{tabular}


Tablo 7’ye göre, moleküler biyoloji öğrencilerinin işletme öğrencilerine göre istatiksel olarak anlamlı bir şekilde "İçe Yansıyan Dışsal Motivasyon" alt boyutunda daha fazla motive oldukları görülmüştür. "Adalet" bölümü öğrencilerinin "Turizm Otelcilik" ve "Uluslararası Ticaret" bölümü öğrencilerine göre istatiksel olarak anlamlı bir şekilde "Motivasyonsuzluk" alt boyutundaki verilere göre daha fazla motive oldukları görülmüştür.

Tablo 8: Sınıflara Göre Ölçek ve Alt Boyutlarının Farklılıklarının İncelenmesi

\begin{tabular}{lccccc}
\hline Faktörler & Bölüm & $\mathbf{N}$ & Ortalama & F & Anlamlıık \\
Dış Belirlenmiş & & & & & \\
& 1. sınıf & 86 & 5,9806 & 3,103 & 0,027 \\
& $3 . \sin ı f$ & 48 & 5,3750 & & \\
Motivasyonsuzluk & 1. sinıf & 85 & 6,0376 & & \\
& 2. sinıf & 113 & 5,3552 & & \\
& 3. sinıf & 48 & 5,1333 & 5,311 & 0,01 \\
& 4. $\sin ı f$ & 100 & 5,3080 & & \\
\hline
\end{tabular}

Tablo 8'de motivasyonsuzluk alt boyutunda, katılımcıların öğrenim gördügü sınıflar açısından anlamlı şekilde farklılaştı̆̆ı bulgulanmıştır. Buna göre farklılıkların hangi alt gruplar arasında gerçekleştiğinin tespit edilmesi amacıyla Tukey testi uygulanmıştır. Testin sonucunda düzenlenen çoklu karşılaştırma tablosuna göre; 1. Sinıf öğrencilerinin 2., 3. ve 4. sınıf öğrencilerine göre istatistiksel olarak anlamlı şekilde motivasyonsuzluklarının daha düşük olduğu görülmüştür. Diğer sınıflar arasında ise, anlamlı bir farklılık bulunmadığı görülmüştür. Belirlenmiş Dişsal Motivasyon alt boyutunda da istatistiksel olarak 1. sınıflar ile 3. sınıfların motivasyon düzeylerinin anlamlı şekilde farklılaştığ 1 , 1 . sınıfların anlamlı bir şekilde 3 . sınıflara göre daha fazla motivasyon hissettiği, diğer sınıfların arasında ise anlamlı bir farklılık bulunmadığ 1 tespit edilmiştir.

Tablo 9: Değişkenler Arasındaki İlişkilere Yönelik Korelasyon Analizi Sonuçları

\begin{tabular}{|c|c|c|c|c|c|c|c|c|}
\hline & 1 & 2 & 3 & 4 & 5 & 6 & 7 & 8 \\
\hline & 1 & & & & & & & \\
\hline \multicolumn{9}{|l|}{ 1.Motivasyonsuzluk } \\
\hline & $\begin{array}{c}346 \\
438^{* *}\end{array}$ & 1 & & & & & & \\
\hline 2.Motivasyon Ölçeği &, 000 & & & & & & & \\
\hline 3.Dışa Bağlı Düzenleme & $\begin{array}{l}, 170^{* * *} \\
, 002\end{array}$ & $\begin{array}{l}, 549^{* * *} \\
, 000\end{array}$ & 1 & & & & & \\
\hline 4. İçe Yansıtma Düzenlemesi & $\begin{array}{l}, 046 \\
, 399\end{array}$ & $\begin{array}{c}, 738^{* * *} \\
, 000\end{array}$ & $\begin{array}{l}, 320^{* *} \\
, 000\end{array}$ & 1 & & & & \\
\hline 5.Belirlenmiş Düzenleme & $\begin{array}{l}, 408^{* * *} \\
, 000\end{array}$ & $\begin{array}{c}, 787^{* *} \\
, 000\end{array}$ & $\begin{array}{l}, 523^{* *} \\
, 000\end{array}$ & $\begin{array}{c}, 456^{* *} \\
, 000\end{array}$ & 1 & & & \\
\hline $\begin{array}{l}\text { 6.Bilmeye Yönelik İçsel } \\
\text { Motivasyon }\end{array}$ & $\begin{array}{l}, 324^{* *} \\
, 000\end{array}$ & $\begin{array}{c}, 848^{* *} \\
, 000\end{array}$ & $\begin{array}{l}, 328^{* *} \\
, 000\end{array}$ & $\begin{array}{c}, 526^{* *} \\
, 000\end{array}$ & $\begin{array}{l}, 600^{* *} \\
, 000\end{array}$ & 1 & & \\
\hline $\begin{array}{l}\text { 7.Başarıya Yönelik İçsel } \\
\text { Motivasyon }\end{array}$ & $\begin{array}{l}, 189^{* *} \\
, 000\end{array}$ & $\begin{array}{l}, 865^{* *} \\
, 000\end{array}$ & $\begin{array}{l}, 301^{* *} \\
, 000\end{array}$ & $\begin{array}{l}, 714^{* *} \\
, 000\end{array}$ & $\begin{array}{l}, 549^{* * *} \\
, 000\end{array}$ & $\begin{array}{l}, 767^{* *} \\
, 000\end{array}$ & 1 & \\
\hline $\begin{array}{l}\text { 8.Uyarım Yaşamaya Yönelik İçsel } \\
\text { Motivasyon }\end{array}$ & $\begin{array}{r}, 126^{*} \\
, 019\end{array}$ & $\begin{array}{c}, 815^{* *} \\
, 000\end{array}$ & $\begin{array}{c}, 238^{* *} \\
, 000\end{array}$ & $\begin{array}{c}, 637^{* *} \\
, 000\end{array}$ & $\begin{array}{l}, 503^{* *} \\
, 000\end{array}$ & $\begin{array}{c}, 740^{* *} \\
, 000\end{array}$ & $\begin{array}{c}, 809^{* *} \\
, 000\end{array}$ & 1 \\
\hline
\end{tabular}

$\mathrm{N}: 350,{ }^{*} \mathrm{p}<0.05, * * \mathrm{p}<0.01$ 
Tablo 9'a göre uygulanan korelasyon analizi sonucunda; dışa bağlı düzenleme alt boyutu ile motivasyonsuzluk alt boyutu arasında pozitif yönde \%17,0'lik doğrusal bir ilişki bulunmaktadır. İçe yansıtma düzenlemesi alt boyutu ile dışa bağlı düzenleme arasında pozitif yönde \%32,0'lik doğrusal bir ilişki bulunmaktadır. Belirlenmiş düzenleme alt boyutunun ilişkili olduğu değişkenler; motivasyonsuzluk alt boyutu arasında pozitif yönde $\% 40,8$ 'lik; dışsa bağlı düzenleme arasında $\% 52,3^{\prime}$ lük; içe yansıtma düzenlemesi arasında ise pozitif yönde $\% 45,6$ ' lık doğrusal bir ilişki bulunmaktadır. Bilmeye yönelik içsel motivasyon alt boyutunun ilişkili olduğu değişkenler; motivasyonsuzluk alt boyutu ile pozitif yönde \%32,4'lük, dişa bağlı düzenleme alt boyutu ile \%32,8'lik, içe yansıtma düzenlemesi alt boyutu ile \%52,6‘l1k, belirlenmiş düzenleme alt boyutu ile $\% 60,0^{\prime}$ lık pozitif yönde doğrusal bir ilişki vardır. Başarıya yönelik içsel motivasyon alt boyutunun ilişkili olduğu değişkenler ise; motivasyonsuzluk alt boyutu ile pozitif yönde \%18,9'luk, dışsa bağlı düzenleme alt boyutu ile pozitif yönde $\% 30,1^{\prime}$ lik, içe yansitma düzenlemesi alt boyutu ile pozitif yönde $\% 71,4$ 'lük, belirlenmiş düzenleme ile pozitif yönde $\% 54,9^{\prime} l u k$, bilmeye yönelik içsel motivasyon ile pozitif yönde \%76,7'lik doğrusal yönde anlamlı bir ilişki vardır. Uyarım yaşamaya yönelik içsel motivasyon alt boyutunun ilişkili olduğu değişkenler ise şu şekildedir; motivasyonsuzluk alt boyutu ile $\% 12,6^{\prime}$ lık, dışa bağlı düzenleme ile $\% 23,8^{\prime}$ lik, içe yansıtma düzenlemesi ile $\% 63,7^{\prime}$ lik, belirlenmiş düzenleme ile $\% 50,3$ 'lük, bilmeye yönelik içsel motivasyon ile $\% 74,0$ 'lük, başarıya yönelik içsel motivasyon ile \%80,9'luk pozitif yönde anlamlı doğrusal bir ilişki olduğu bulgulanmıştır.

Tablo 10: Motivasyonsuzluk Alt Boyutu ile Demografik Faktörlerin İlişkisi

\begin{tabular}{lcccc}
\hline Faktörler & & Yaş & Sinıf & Aile Geliri \\
& $\mathbf{r}$ &,$- 132^{*}$ &,$- 160^{* *}$ &,$- 191^{* *}$ \\
Motivasyonsuzluk & Anlamlılık &, 014 &, 003 &, 000 \\
& $\mathrm{~N}$ & 346 & 346 & 346 \\
\hline
\end{tabular}

$* \mathrm{p}<0.05, * * \mathrm{p}<0.01$

Tablo 10'a göre motivasyonsuzluk ölçeği ile katılımcıların yaşları, öğrenim sınıfları ve aile gelirleri değişkenleri arasında negatif yönde ve zayıf kuvvette anlamlı bir ilişki olduğu görülmüştür. Diğer bir ifade ile katılımcıların yaşı, öğrenim sınıfı ve aile gelirleri yükseldikçe motivasyonsuzlukları düşmekte, ya da tam tersi şeklide düştükçe yükselmektedir.

Tablo 11: Uyarım Yaşamaya Yönelik İçsel Motivasyon Alt Boyutu ile Demografik Faktörlerin İlişkisi

\begin{tabular}{lcc}
\hline Faktörler & & Yaş \\
Uyarım Yaşamaya Yönelik İçsel Motivasyon & $\mathrm{r}$ &, $156^{* *}$ \\
& Anlamlılık &, 003 \\
\hline $\mathrm{p}<0.05, * * \mathrm{p}<0.01$ & $\mathrm{~N}$ & 347 \\
\hline
\end{tabular}

Tablo 11'e göre, katılımcıların "Uyarım Yaşamaya Yönelik İçsel Motivasyon" alt boyutu ile yaşları arasında istatiksel olarak, pozitif yönde ve zayıf kuvvette anlamlı bir ilişki olduğu görülmüştür. Diğer bir ifadeyle, katılımcıların yaşı yükseldikçe belirtilen alt boyuttaki akademik motivasyonu da artmaktadır. 


\section{SONUÇ}

Motivasyon, insan hayatının her düzeyinde ihtiyaç duyulan bir kavram olarak ifade edilebilir. Akademik motivasyon ise okul hayatındaki öğrencilerin başarılarını etkileyen ve bireyi çalışmaya yönlendiren tüm süreçleri içermektedir. Bireyin ulaşmak istediği amaç ve hedefler doğrultusunda güdülenmesi ile birlikte birey davranışı gerçekleştirir. Akademik motivasyonun ele alındığ 1 bu çalışma ile küresel salgın dönemi olan Covid-19 süreçlerinin öğrencilerin akademik motivasyon durumlarına etkisinin tespit edilmesi amaçlanmıştır.

Uşak Üniversitesi öğrencilerinden elde edilen veriler sonucunda yapılan analiz sonuçlarına göre, katılımcıların akademik motivasyon düzeyleri demografik faktörlerden etkilenmektedir. Cinsiyet değişkeni açısından; kadın katılımcıların erkek katılımcılara göre motivasyon düzeyleri daha yüksek olduğu bulgulanmıştır. Covid-19 geçiren katılımcıların, geçirmeyenlere göre başarıya yönelik içsel motivasyon düzeyleri daha düşük düzeydedir. Bu durum Covid-19 sürecinin bireyler üzerindeki fiziki ve ruhsal etkilerinin sonucu olduğu söylenebilir. Tüm dünyayı etkisi altına olan Covid-19 pandemisinin bireylerin başarıya yönelik içsel motivasyon düzeylerini de etkilediği ifade edilebilir. Katılımcıların ailesinde bu hastalığı geçirenlerin, geçirmeyenlere göre ise, bilmeye yönelik içsel motivasyon düzeylerinin daha düşük olduğu bulgulanmıştır. $\mathrm{Bu}$ bağlamda bilmeye yönelik içsel motivasyon bireyin yeni şeyler öğrenirken keyif almasını açıkladığı için, katılımcıların ailesinde Covid-19 geçiren bireylerin bulunması bireyin yeni şeyler öğrenme aktivitesinden keyif alma düzeyini düşürebilecektir ve aynı zamanda da tamamen bireyin içinden gelerek bir aktivitenin gerçekleştirmesini ifade eden bilmeye yönelik içsel motivasyon süreçlerinin ailede hasta birey olmasından etkilenebileceği söylenebilir. Pandemi döneminde kariyer planlarını değiştiren katılımcılar ile kariyer planlarında değişiklik yapmayan katılımcıların akademik motivasyon ve içsel motivasyonu oluşturan bilmeye yönelik içsel motivasyon, başarmaya yönelik içsel motivasyon ve uyarım yaşamaya yönelik içsel motivasyon boyutlarında anlamlı farklılıklar olduğu bulgulanmıştır. Pandemi döneminde kariyer planlarını değiştiren katılımcıların motivasyon düzeylerinin kariyer planını değiştirmediğini ifade eden katılımcılara göre, motivasyon düzeylerinin yüksek olduğu tespit edilmiştir. Pandemi döneminin kariyer planları ile ilgili değişiklikleri planlama konusunda da bireyler açısından farklılık gösterdiği belirtilebilir.

Öğrencilerin bölümleri açısından; motivasyon düzeyleri arasında istatistiksel olarak anlamlı farklılıklar bulgulanmıştır. Bu kapsamda Moleküler biyoloji bölümünde okuyan öğrencilerin işletme bölümü öğrencilerine göre içe yansıyan dışsal motivasyon düzeylerinin daha yüksek olduğu tespit edilmiştir. İçe yansıyan dışsal motivasyon düzeyi bireyin kişisel beklentilerinin karşılanıp karşılanmamasına bağlı olarak değişen bir durumu ifade ettiği için moleküler biyoloji bölümü öğrencilerinin kişisel beklentilerinin karşılanması durumunun işletme öğrencilerine göre daha fazla olduğu belirtilebilir. Adalet bölümü öğrencilerinin turizm otelcilik ve uluslararası ticaret bölümü öğrencilerine göre ise, motivasyonsuzluk alt boyutunda daha fazla motive oldukları görülmüştür. Motivasyonsuzluk bireyin güdülenmemesi sonucu davranış geliştirmemesi durumudur. Adalet bölümü öğrencilerinin turizm ve otelcilik, uluslararası ticaret bölümü öğrencilerine göre kamuya atanabilme olasılıklarının yüksek olması, öğrencilerin motivasyon düzeylerini de olumlu etkileyebilecektir. Bu nedenle çalışmada adalet bölümü öğrencilerinin kamu kurum ve kuruluşlarına atanmada daha yüksek oranda tercih edildiği olgusunun böyle bir sonuç ortaya çıkmasında etkili olabileceği söylenebilir. Öğrencilerin sınıf düzeyleri arasında ise 1. Sınıf öğrencilerinin 2., 3., ve 4. Sınıf öğrencilerine göre istatistiksel olarak motivasyonsuzluklarının daha düşük düzeyde olduğu bulgulanmıştır. Diğer bir ifade ile 1 . Sınıf öğrencilerinin motivasyon düzeylerinin diğer sınıflara göre daha yüksek olduğu ifade edilebilir. Elde edilen araştırma bulgularına göre akademik motivasyon düzeyinin demografik faktörler açısından farklılaştığı görülmüştür. Küresel salgın döneminin getirdiği bir sonuç olarak öğrencilerin akademik motivasyon düzeylerinin pandemi döneminden etkilendiği bulgulanmıştır. Covid-19 hastalığına yakalanan katılımcıların başarıya yönelik içsel motivasyon düzeylerinin 
düşük olduğu, ailesinde Covid-19 hastalığına yakalanan katılımcıların ise bilmeye yönelik içsel motivasyonlarının düşük düzeyde olduğu tespit edilmiştir. Bu bağlamda pandemi döneminin ve hastalığ geçirme durumunun öğrencilerin içsel motivasyon düzeylerinde etkisi olduğu belirtilebilir.

Araştırmanın kısıtı pandemi döneminde Covid-19 ile mücadele kapsamında alınan tedbirler ve örneklemin yalnızca Uşak Üniversitesi öğrencileri ile sınırlandırılmasıdır. Gelecekteki yapılacak çalışmalarda araştırmacılar, araştırma örneklemini genişletebilir ve farklı üniversitelerde öğrenim gören öğrenciler üzerinde de uygulayabilirler. Bu sayede ülke genelinde çeşitli üniversitelerde öğrenim gören öğrencilerin motivasyon düzeyleri ve motivasyonlarını etkileyen faktörler belirlenerek daha kapsamlı karşılaştırma ve analiz yapılabilecektir. Öğrencilerin akademik motivasyon düzeylerini etkileyen faktörlerin belirlenmesi, üniversite yönetimlerine pandemi döneminde öğrencilerin motivasyonunu artırmaya yönelik olarak neler yapabilecekleri konusunda yol gösterici olabilecektir. Bu konuda üniversiteler online destek sistemleri kurabilir, plan ve programlar oluşturarak ortaya çıkabilecek olan beklenmedik olağanüstü durumlar için geniş tedbirler alabilirler.

\section{Araştırma ve Yayın Etiği Beyanı}

Bu çalışma Uşak Üniversitesi Sosyal ve Beşerî Bilimler Bilimsel Araştırma ve Yayın Etiği Kurulunun 09.03.2021 tarih ve 2021-49 sayılı kararı Etik Kurul Onay Belgesi ile bilimsel araştırma ve yayın etiğgi kurallarına uygun olarak hazırlanmışıır.

\section{Yazarların Makaleye Katkı Oranları}

Yazar 1'in makaleye katkıs1 \%50, Yazar 2'nin makaleye katkıs1 \%50'dir.

\section{Çıkar Beyanı}

Yazarlar açısından ya da üçüncü taraflar açısından çalışmadan kaynaklı çıkar çatışması bulunmamaktadır.

\section{KAYNAKÇA}

Akbaba, S. (2006). Eğitimde motivasyon. Kazım Karabekir Eğitim Fakültesi Dergisi, 13, 343-361.

Başaran, İ. E. (2008). Örgütsel davranış insanın üretim gücü, BRC Baskı. Ankara.

Brophy, J. (2012). Motivating students to learn. Routledge: New York.

Clark, M. H. \& Schroth C.A. (2010). Examining relationships between academic motivation and personality among. Learning and Individual Differences, 20 (2010) 19-24. doi: 10.1016/j.lindif.2009.10.002

Deci, E. L. \& Ryan, R. M. (2000). The "what" and "why" of goal pursuits: human needs and the self-determination of behavior. Psychological Inquiry, 11(4), 227-268.

Gayne, M. \& Deci, E.L. (2005). Self-determination theory and work motivation. Journal of Organizational Behavior, 26 (4). 331-362.

Gömleksiz, M. N. ve Serhatlığlu, B. (2013). Öğretmen adaylarının akademik motivasyon düzeylerine ilişkin görüşleri, TSA, 17(3), 99-128.

Grigoryeva, M. V.\& Shamionov, R. M. (2014). Predictors of emotional well-being and academic motivation in junior schoolchildren. Procedia-Social and Behavioral Sciences, 146 (2014) 334 - 339. doi: 10.1016/j.sbspro.2014.08.106.

Günaydın, H.D. (2021). The impact of social problem skills on academic motivation by means of Covid-19 fear A sem model: social problem solving, Covid-19, academic motivation. Current Psychology. https://doi.org/10.1007/s12144-021-01665-Z

Korkmazer (2020). Üniversite öğrencilerinin akademik motivasyon algılarının incelenmesi üzerine bir alan çalışması. Dicle Üniversitesi İ̈BF Dergisi, 10 (20), 502-515. 
Lia , L., Penga , Z., Lua , L. Huan Liaoa , H. \& Li, H. (2020). Peer relationships, self-efficacy, academic motivation, and mathematics achievement in zhuang adolescents: A moderated mediation model. Children and Youth Services Review, 118, 105358. doi.org/10.1016/j.childyouth.2020.105358

Moghadam, M. T., Abbasi, E., Khoshnodifar, Z. (2020). Students' academic burnout in iranian agricultural higher education system: the mediating role of achievement motivation. Heliyon, 6 (2020) e04960. https://doi.org/10.1016/j.heliyon.2020.e04960

Nye, C.D., Prasad, J. \& Rounds, J. (2021). The effects of vocational interests on motivation, satisfaction, and academic performance: test of a mediated model. Journal of Vocational Behavior, 127 (2021) 103583. https://doi.org/10.1016/j.jvb.2021.103583

Özkan, Ö. N., Akın, S. ve Durna, Z. (2015). Hemşirelik öğrencilerinin liderlik yönelimleri ve motivasyon düzeyleri. Hemşirelikte Ĕ̈itim ve Araştırma Dergisi, 12 (1): 51-61. doi:10.5222/HEAD.2015.051.

Özgün, E. (2019). Uygulamalı olan ve olmayan sağlık hizmetleri meslek yüksekokulu önlisans öğrencilerinin girişimcilik ve akademik motivasyon açısından karşılaştırmalı incelenmesi. İstanbul Gelişim Üniversitesi Sağlık Bilimleri Enstitüsü, YL Tezi. İstanbul.

Romero, R. H., Hall, J., Cluver, L., Meinck, F. \& Hinde, E. (2018). How does exposure to violence affect school delay and academic motivation for adolescents living in socioeconomically disadvantaged communities in South Africa? Journal of Interpersonal Violence, 1-34. doi: 10.1177/088626051877959.

Rowell, L. \& Eunsook Hong, E. (2013). Academic motivation: concepts, strategies, and counseling approaches. Professional School Counseling, 16 (3), 158-171.

Ryan, R. M., \& Deci, E. L. (2000). Self-determination theory and the facilitation of intrinsic motivation, social development, and well-being. American Psychologist, 55, 68-78.

Sanaie, N., Vasli., P., Sedighi, L. \& Sadeghi, B. (2019). Comparing the effect of lecture and jigsaw teaching strategies on the nursing students' self-regulated learning and academic motivation: a quasiexperimental study. Nurse Education Today, 79 (2019) 35-40. https://doi.org/10.1016/j.nedt.2019

Şenturan, Ş. (2014). Örnek olaylarla örgütsel davranış, 1. Baskı. Beta Basım. İstanbul.

Tam, H., Kwok, S.Y.C.L., Hui, A.N.N., Chan, D.K., Leung, C., Leung, J., Lo, H.\&Lai, S. (2020). The significance of emotional intelligence to students' learning motivation and academic achievement: A study in hong kong with a confucian heritage. Children and Youth Services Review, $121 \quad$ (2021) 105847. https://doi.org/10.1016/j.childyouth.2020.105847

Terlemez, B., Şahin, D.\& Dilek, F. (2015). Namık kemal üniversitesi sağlık hizmetleri meslek yüksekokulu öğrencilerinin akademik motivasyon düzeyleri. Pamukkale Journal of Eurasian Socioeconomic Studies, 2 (2), 67-78. doi:10.5505/pjess.2015.09797.

Vallerand, R. J., Pelletier, L.G., Blais, M. R., Briére, N. M., Senécal C., Valliéres, E. F. (1992). The academic motivation scale: a measure of intrinsic, extrinsic, and a motivation in education. Educational and Psychological Measurement, 52, ss.1003-1017.

Vallerand, R. J. (1989). Construction et validation de i'echelle de motivation en education (EME)", Revue Canadienne des Sciences Du Comportement. 21 (1), 323-349.

Xie, K., Vongkulluksn, V. W., Lu, L. \& Cheng, S. (2020). A person-centered approach to examining high-school students' motivation, engagement and academic performance. Contemporary Educational Psychology, 62 (2020) 101877. https://doi.org/10.1016/j.cedpsych.2020.101877

Yılmaz, M., Taşkesen, O. \& Taşkesen, S. (2015). Güzel sanatlar eğitimi bölümü öğrencilerinin bazı değişkenlere göre akademik motivasyonları ile akademik başarıları arasındaki ilişkinin incelenmesi, Erzincan Üniversitesi Ĕ̈itim Fakültesi Dergisi, 18(2). 1056-1072.doi. 10.17556/jef.62310.

Zencirkıran, M. ve Keser, A. (2018). Örgütsel Davranış. Dora Basım. 1. Baskı. Bursa. 


\section{Extended Summary}

\section{Investigation of University Students' Academic Motivation Levels in the Period of Pandemic}

The concept of motivation, which has an important place in human life, directs the individual to behaviors that guide her and meet her wishes and needs. Motives that affect human behavior can produce physiological and psychological effects. The pandemic period, which affects the whole world, can also have physiological and psychological effects on people. From this point of view, this study aimed to determine the academic motivation levels of university students during the pandemic period. Motivation is when an individual is motivated towards a behavior. In the pandemic period, it was tried to determine the effect of the motivations of the individuals on academic motivation. Academic motivation can be expressed as the power that directs the individual to a behavior and work for her learning life. Thus, it shapes the behavior of the individual. Addressing the study during the pandemic period will contribute to the relevant literature. Although there are different studies in the literature to determine the motivation levels of students in normal periods, no study has been found during the pandemic period. This constitutes the original aspect of his work. In this study, academic motivation levels of university students were examined. A study was conducted on students studying at Usak University. Faculty and college students from different departments participated in the research. Data were collected through an online survey. The questionnaire form includes questions about academic motivation scale and demographic factors. 351 students participated. The obtained data were analyzed with statistical methods. Relationships between variables were made by T-test, Anova and Correlation analysis.

According to the findings obtained from the research; academic motivation levels are affected by demographic factors. In terms of gender variable, it was found that female participants had higher motivation levels than male participants. Participants who have had Covid-19 have a lower level of intrinsic motivation for success than those who have not. It can be stated that the Covid-19 pandemic also affects the intrinsic motivation levels of individuals for success. It was found that those who had this disease in the family of the participants had lower levels of intrinsic motivation to know than those who did not. It was found that there were significant differences in the dimensions of academic motivation and intrinsic motivation to know, intrinsic motivation to achieve, and intrinsic motivation to experience stimulation, which constitute academic motivation and intrinsic motivation, with participants who changed their career plans during the pandemic period. It was determined that the motivation levels of the participants who changed their career plans during the pandemic period were higher than the participants who stated that their career plans did not change. In terms of students' departments, statistically significant differences were found between motivation levels. In this context, it has been determined that the students studying in the molecular biology department have higher levels of introverted extrinsic motivation than the students in the business department. Among the grade levels of the students, it was found that the 1 st grade students were statistically less motivated than the $2 \mathrm{nd}$, 3rd, and 4th grade students. In other words, it can be stated that the motivation levels of the 1st grade students are higher than the other grades. According to the research findings, it can be said that the level of academic motivation differs in terms of demographic factors. As a result of the global epidemic period, it is seen that the academic motivation levels of the students are affected by the pandemic period. It has been determined that the intrinsic motivation levels of the participants with the Covid-19 disease are low, and the intrinsic motivation to know is low in the participants who have the Covid-19 disease in their families. In this context, it can be stated that the pandemic period and the state of having the disease have an effect on the students' intrinsic motivation levels. It may differentiate the research sample in future studies. Comparisons can be made by making different departments in different universities. Determining the factors that affect the academic motivation levels of the 
students will guide the university administrations about what they can do to increase the motivation of the students during the pandemic period. In this regard, universities can establish online support systems and take extensive measures for unexpected, extraordinary situations that may arise by creating plans and programs. It has been found that the academic motivation levels of the students during the pandemic period differ according to demographic factors and whether they have covid-9 patients or not. Organizing online activities that can increase the motivation of students in such extraordinary situations can be elements that will increase the motivation of individuals. In this context, it should be included in the action plans that the relevant institutions and organizations organize activities that increase the morale and motivation of both their employees and students and create support systems in the face of unexpected situations such as the pandemic period. With this aspect of the research, it can also have a guiding role for decision makers. In this context, it should be included in the action plans that the relevant institutions and organizations organize activities that increase the morale and motivation of both their employees and students and create support systems in the face of unexpected situations such as the pandemic period. With this aspect of the research, it can also have a guiding role for decision makers. When the problems related to the factors affecting the academic motivation process are eliminated, the students will act by setting goals and targets for achieving academic success. Motivation refers to the process of realizing the action with the effect of the motives of the action. This process can be affected by many internal and external factors. In this context, factors that increase the motivation of individuals will contribute to exhibiting positive behaviors. 